\title{
Perbandingan Hasil Belajar Fisika dengan Menggunakan Bahan Ajar E-Materi Berbasis Exe dengan E-Materi Berbasis Powerpoint pada Siswa Kelas XI SMA Negeri 6 Palu
}

\author{
Eka Anggriani \\ Email: anggrianieka25@yahoo.co.id \\ Program Studi Pendidikan Fisika, Jurusan Pendidikan MIPA, Universitas Tadulako \\ Jln. Soekarno Hatta Km. 9 Kampus Bumi Tadulako Tondo Palu - Sulawesi Tengah
}

\begin{abstract}
Abstrack - Penelitian ini bertujuan untuk mengetahui perbandingan hasil belajar fisika dengan menggunakan bahan ajar E-Materi berbasis Exe dengan E-Materi berbasis Powerpoint pada siswa kelas XI SMA Negeri 6 Palu. Penelitian ini menggunakan desain penelitian "Posttest-Only Comparison Group Design" Populasi dari penelitian ini adalah seluruh siswa kelas XI SMA Negeri 6 Palu. Kelas XI IPA ${ }_{1}$ diajar menggunakan bahan ajar E-Materi berbasis Exe sedangkan kelas XI IPA 2 diajar menggunakan bahan ajar E-Materi berbasis Powerpoint. Instrumen yang digunakan pada penelitian ini adalah tes hasil belajar fisika dalam bentuk multiple choice dan essay. Berdasarkan hasil pengolahan data diperoleh hasil belajar fisika untuk kelas XI IPA $A_{1}$ rata-rata 70,86 dengan standar deviasi 8,83 dan untuk kelas XI IPA 2 diperoleh rata-rata 60,24 dan standar deviasi 11,40. Uji hipotesis, pada penelitian ini $\mathrm{H}_{0}$ ditolak sedangkan $\mathrm{H}_{1}$ diterima. Maka dapat disimpulkan bahwa terdapat perbedaan hasil belajar fisika antara siswa yang menggunakan bahan ajar E-Materi berbasis Exe dengan siswa yang menggunakan E-Materi berbasis poweroint.
\end{abstract}

Kata Kunci: Hasil Belajar Fisika, E-Materi Berbasis Exe,dan E-Materi Berbasis Powerpoint

\section{PENDAHULUAN}

Pada era teknologi informasi dewasa ini, peran multimedia sangat penting dan keberadaanya sudah merambah hampir seluruh aspek kehidupan baik ekonomi, politik, sosial, budaya, dan tidak terkecuali pendidikan.

Pada saat ini, hampir setiap sekolah menengah memiliki komputer, akan tetapi keberadaanya di sekolah hanya digunakan untuk keperluan administrasi seperti mengolah data dan mengetik laporan bukan digunakan sebagai media pembelajaran sehingga sebagian besar guru masih menggunakan metode lama yaitu pembelajaran dengan metode ceramah. Hal inilah yang biasa membuat siswa jenuh dalam proses kegiatan belajar mengajar sehingga dapat membuat hasil belajar siswa menjadi kurang memuaskan. Padahal di era teknologi informasi saat ini.

Komputer dapat digunakan sebagai salah satu sumber belajar. Menurut Oemar (dalam Saehana, 2004) bahwa "sebagai suatu sumber belajar, komputer adalah suatu alat bagi siswa yang memberikan atau menyediakan informasi tetapi komputer bukan sebagai guru itu sendiri". Keberhasilan proses belajar mengajar tidak hanya ditentukan oleh pendidik (guru) maupun peserta didik, tetapi juga dipengaruhi oleh sarana pembelajaran yang digunakan. Salah satu aplikasi yang dapat digunakan untuk membuat bahan ajar adalah eXe (eLearning $X H T M L$ editor). Dengan aplikasi tersebut, seorang pendidik dalam membuat bahan ajar tidak harus menguasai pemrograman HTML karena aplikasi tersebut siap pakai. Yang diperlukan oleh seorang pendidik adalah kemauan dan memahami materi yang akan disampaikan, sehingga hasil bahan ajar yang dibuat akan komunikatif dan mudah dipahami oleh peserta didik (siswa) sehingga berpengaruh pada prestasi atau hasil belajar siswa.

Penyebab pemilihan media dalam belajar adalah ingin memberikan atau menyajikan gambaran materi atau penjelasan yang lebih konkret sehingga dapat menarik minat atau gairah belajar siswa. Briggs berpendapat bahwa media adalah segala alat fisik yang dapat menyajikan pesan serta merangsang siswa untuk belajar.

Alat atau media pembelajaran merupakan salah satu komponen yang sangat penting untuk peningkatan kemampuan anak didik dalam proses belajar mengajar. Salah satu media pembelajaran yang banyak digunakan adalah OHP (Over head Projektor), namun 
dalam pelaksanaannya penggunaan OHP (Over head Projektor) tidak praktis. Berbeda dengan media pembelajaran Microsoft PowerPoint yang sangat mudah dioperasikan melalui bantuan komputer dan proyektor LCD, seorang pendidik dapat menyampaikan materi dengan mudah dan tampilan materi yang disajikan dapat menarik minat belajar siswa.

Menurut Johandayani (2009) Microsoft PowerPoint adalah suatu software yang menyediakan fasilitas yang dapat membantu dalam menyusun sebuah presentasi yang efektif, profesional, dan juga mudah. Microsoft PowerPoint akan membantu menyampaikan suatu gagasan menjadi lebih menarik dan jelas tujuannya. Dengan fasilitas serta kemudahan penggunaan yang dimiliki software ini memungkinkan para guru Sekolah untuk memanfaatkannya sebagai media pembelajaran yang baik. Dari hasil penelitian Karim Hidayat Sholihin menyimpulkan bahwa media pembelajaran dengan PowerPoint yang dikembangkan layak digunakan sebagai pendukung pembelajaran yang efektif untuk meningkatkan prestasi belajar siswa.

Berdasarkan uraian di atas, peneliti bermaksud untuk melakukan penelitian tentang perbandingan hasil belajar fisika dengan menggunakan bahan ajar e-materi berbasis exe dengan e-materi berbasis PowerPoint pada siswa kelas XI SMA Negeri 6 Palu.

\section{METODOLOGI}

Penelitian ini merupakan penelitian eksperimen kuasi dengan mengambil sampel secara sampling jenuh pada sekolah SMA Negeri 6 Palu. Kedua kelas eksperimen ini yaitu kelas XI IPA ${ }_{1}$ sebagai kelas eksperimen pertama yang meggunakan bahan ajar E-Materi berbasis Exe dengan jumlah siswa sebanyak 21 siswa dan sebagai kelas eksperimen kedua yang menggunakan bahan ajar E-Materi berbasis powerpoint dengan jumlah siswa sebanyak 21 siswa. Ruang lingkup dalam penelitian ini adalah hasil belajar siswa materi Elastisitas dan Gerak harmonik Sederhana.

Data yang diambil dari penelitian ini yaitu hasil belajar siswa berupa tes yang diberikan pada akhir materi pembelajaran. Untuk lebih jelasnya desain penelitian yang digunakan dalam penelitian ini adalah sebagai berikut:
ISSN 23383240

TABEL 1. POSTTEST ONLY COMPARISON GROUP DESIGNDESAIN PEMBANDING KELOMPOK DAN POST-TES (SYAODIH, 2011).

\begin{tabular}{|c|c|c|}
\hline Kelompok & Perlakuan & Post Test \\
\hline $\mathrm{A}(\mathrm{KE})$ & $\mathrm{X}_{\mathrm{A}}$ & $\mathrm{O}$ \\
$\mathrm{B}(\mathrm{KE})$ & $\mathrm{X}_{\mathrm{B}}$ & $\mathrm{O}$ \\
\hline
\end{tabular}

\section{HASIL DAN PEMBAHASAN}

Tabel 2. Nilai rata-rata dan standar deviasi hasil belajar fisika kelas XI IPA 1 yang diajar menggunakan bahan ajar EMateri berbasis exe dan E-Materi berbasis powerpoint.

\begin{tabular}{|c|c|c|}
\hline Uraian & Powerpoint & Exe \\
\hline Rata-rata & 60,24 & 70,86 \\
\hline $\begin{array}{c}\text { Satndar } \\
\text { deviasi }\end{array}$ & 11,40 & 8,83 \\
\hline
\end{tabular}

\section{Pengujian Hipotesis Tes Hasil Belajar Fisika Siswa Kelas A dan B}

Berdasarkan syarat dan ketentuan, $\mathrm{H}_{0}$ diterima jika $\left.\left.-t_{(1-1 / 2} a\right)<t<t_{(1-1 / 2} a\right)$ pada taraf nyata $a=0,05$ dan $d k=n_{1}+n_{2}-2=21$ $+21-2=40$ pada tabel distribusi diperoleh $t_{0,975(40)}=2,02$ dan thitung $=3,47$. Hal ini berarti nilai thitung berada diluar penerimaan $\mathrm{H}_{0}$. Dengan demikian $\mathrm{H}_{0}$ ditolak sedangkan $\mathrm{H}_{1}$ diterima.

Tujuan dari penelitian ini adalah untuk mengetahui perbedaan hasil belajar fisika dengan menggunakan bahan ajar E-Materi berbasis Exe dengan E-Materi berbasis powerpoint pada siswa kelas XI SMA Negeri 6 Palu. Subjek penelitian ini adalah kelas XI IPA ${ }_{1}$ sebagai kelas eksperimen pertama dan kelas eksperimen kedua adalah kelas XI IPA . Penelitian ini tidak menggunakan model pembelajaran namun yang berbeda adalah penyajian materinya dalam bentuk Exe pada kelas eksperimen pertama dan penyajian materi dalam bentuk powerpoint pada kelas eksperimen kedua.

Berdasarkan hasil uji hipotesis dengan diterimanya $\mathrm{H}_{1}$ berarti terdapat perbedaan hasil belajar fisika dengan menggunakan bahan ajar E-Materi berbasis Exe dengan E-Materi berbasis powerpoint. Hal ini dapat dilihat dari nilai ratarata yang diperoleh siswa kelas XI IPA 2 dan kelas XI IPA 2 masing-masing 70,86 dan 60,24. Dilihat dari nilai rata-rata siswa yang mengikuti pembelajaran dengan menggunakan bahan ajar E-Materi berbasis Exe lebih tinggi dibanding dengan siswa yang mengikuti pembelajaran dengan menggunakan powerpoint. Hal ini juga didukung oleh hasil pengujian hipotesis yaitu thitung berada diluar daerah penerimaan.

Adanya perbedaan hasil belajar yang diperoleh siswa kelas XI IPA ${ }_{1}$ dan siswa kelas XI $\mathrm{IPA}_{2}$ dipengaruhi oleh beberapa faktor. Faktor utama adalah bahan ajar yang digunakan pada 
kelas XI IPA 1 dan kelas XI IPA $\mathrm{I}_{2}$ berbeda sehingga hasil belajar yang diperoleh kedua kelas juga berbeda.

Pada kelas XI IPA ${ }_{1}$ menggunakan bahan ajar E-Materi berbasis Exe. Exe ini berupa buku ajar elektronik. Tampilannya seperti pada gambar di bawah ini

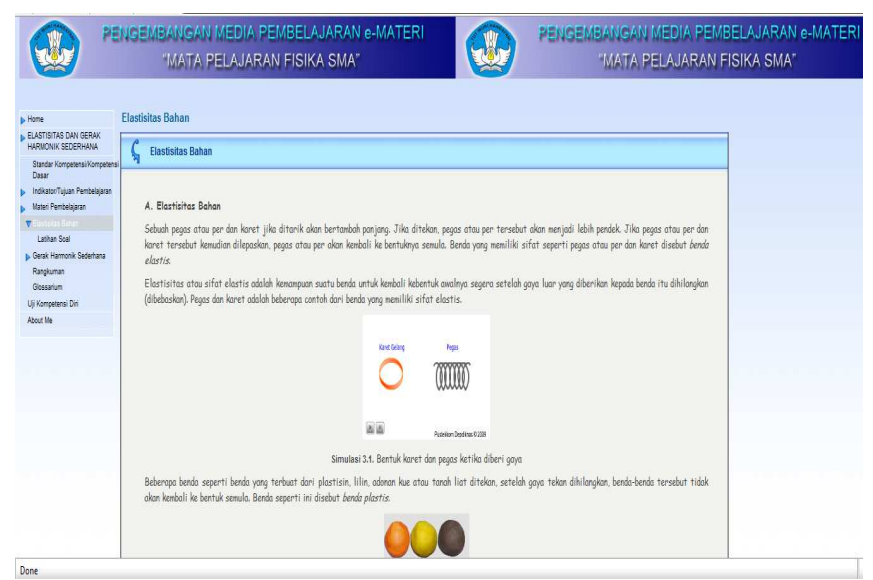

Materi yang ditampilkan pada exe sangat lengkap dan diuraikan sangat jelas, materi yang disajikan juga disertakan dengan contoh-contoh soal, exe juga dapat menampilkan fakta-fakta fisika dalam bentuk gambar, diagram, animasi, simulasi, dan video sehingga siswa tidak hanya membaca rumus-rumus, membayangkan atau menghayal mengenai materi fisika yang diajarkan khususnya pada materi Elastisitas dan Gerak Harmonik Sederhana. Oleh karena itu siswa yang mengikuti pembelajaran dengan menggunakan bahan ajar E-Materi berbasis Exe lebih aktif, lebih mengerti, lebih paham dan lebih semangat mengikuti pelajaran fisika sehingga berdampak pada hasil belajar dan prestasi belajar siswa.

Sedangkan pada kelas XI IPA 2 menggunakan bahan ajar E-Materi berbasis powerpoint. Powerpoint adalah bahan ajar elektronik. Materi yang ditampilkan berbeda dengan exe. Pada Powerpoint materinya ditampilkan seperti gambar

\section{A. Elartiritas Bahan}

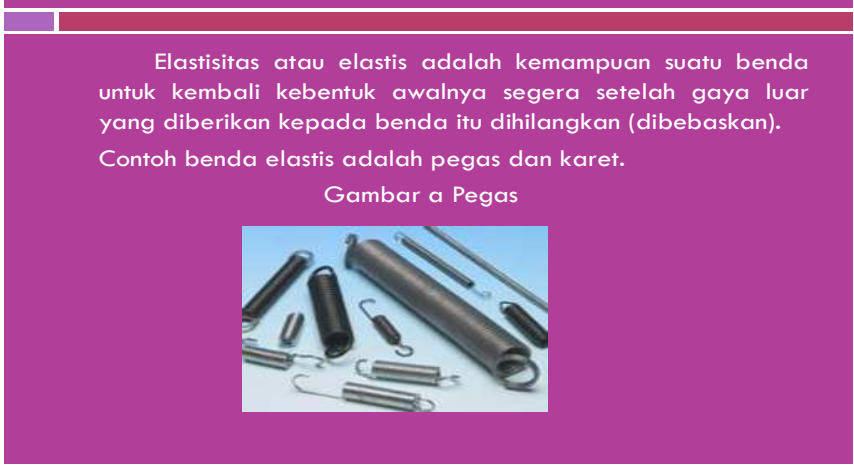

Materi yang ditampilkan kurang lengkap karena hanya menampilkan materi secara slide per slide hanya garis-garis besar materi saja yang ditampilkan kepada siswa seperti yang terlihat pada gambar diatas sehingga menyulitkan siswa memahami materi yang diajarkan. Oleh karena itu guru biasa hanya dikatakan mempresentasikan materi pelajaran pada siswa.

Dengan melihat perbedaan masing-masing kedua bahan ajar tesebut maka sudah dapat terlihat pula perbedaan hasil belajar yang yang dicapai oleh siswa yang menggunakan bahan ajar E-Materi berbasis exe dan siswa yang menggunakan bahan ajar E-Materi berbasis powerpoint.

Pada kelas yang menggunakan bahan ajar E-Materi berbasis exe 14 siswa dalam kelas tersebut mencapai nilai 70 keatas dan 7 siswa yang mencapai nilai 70 kebawah. Sedangkan pada kelas yang menggunakan bahan ajar EMateri berbasis powerpoint 5 siswa yang mencapai nilai 70 keatas selebihnya memperoleh nilai 70 kebawah. Berarti penggunaan bahan ajar E-Materi berbasis exe lebih dimengerti oleh siswa penyajian materinya dibandingkan dengan menggunakan powerpoint.

Tidak menutup kemungkinan adanya perbedaan hasil belajar ini juga disebabkan oleh faktor lain, diantaranya tingkat kecerdasan siswa. Ada siswa yang lebih cepat mengerti dan ada siswa lambat mengerti.

Pembelajaran dengan menggunakan media komputer seperti ini sangat baik digunakan karena dapat membuat siswa lebih aktif. Hal ini didikung oleh pendapat soeharto (dalam Yelvi Elita 2008) yang mengemukakan bahwa "Dengan menggunakan media pembelajaran secara tepat dan bervariasi dapat mengatasi sikap pasif anak didik, karena dengan menggunakan media yang menampilkan fakta 
dalam bentuk model, rekaman suara, gambar, video, animasi, diagram, model akan dapat menimbulkan kegairahan belajar bagi siswa, dan menimbulkan persepsi yang sama".

\section{KESIMPULAN DAN SARAN}

Berdasarkan analisis data hasil penelitian dapat disimpulkan bahwa terdapat perbedaan hasil belajar fisika dengan menggunakan bahan ajar E-materi berbasis exe dengan E-Materi berbasis powerpoint. . Hal ini dibuktikan dengan hasil uji hipotesis dimana nilai thitung $>$ tabel.

Sesuai hasil penelitian yang telah diperoleh, maka peneliti memberikan saran yaitu Sebaiknya penggunaan bahan ajar E-Materi berbasis Exe dan E-Materi berbasis powerpoint di desain lebih baik lagi.

\section{PUSTAKA RUJUKAN}

[1] Arikunto, S. 2005. Dasar-Dasar Evaluasi Pendidikan. Jakarta: Bumi Aksara.

[2] Johandayani. 2009. Pengaruh Media Microsoft PowerPoint terhadap Hasil Belajar Siswa. Malang.Universitas Negeri Malang.

[3] Warjana, dan Razaq, Abdul. 2009. Membuat Bahan Ajar Berbasis Web dengan eXe. Jakarta. PT Elex Media Komputindo. 